\title{
Development of Corporate Bond Markets in Emerging Market Countries: Empirical Evidence from Bosnia and Herzegovina
}

\author{
Nedžad Polić ${ }^{1}$, Emira Kozarević ${ }^{2} \&$ Jasmina Džafić $^{1}$ \\ ${ }^{1}$ Faculty of Economics, Zenica University, Zenica, Bosnia and Herzegovina \\ ${ }^{2}$ Faculty of Economics, Tuzla University, Tuzla, Bosnia and Herzegovina \\ Correspondence: Emira Kozarević, Faculty of Economics, Tuzla University, Tuzla, Bosnia and Herzegovina. Tel: \\ 387-61-178-821. E-mail: emira.kozarevic@untz.ba
}

Received: January 25, 2015

Accepted: February 9, 2015

Online Published: March 25, 2015

doi:10.5539/ibr.v8n4p180

URL: http://dx.doi.org/10.5539/ibr.v8n4p180

\begin{abstract}
In the countries with developed financial markets, unlike in Bosnia and Herzegovina (BiH) and other emerging market countries (EMCs) with the so called bank-centric financial systems, corporate bonds are a rather significant alternative to the usage of bank loans for financing the development needs of the real sector of the economy (corporate sector). The new architecture of world's financial stability with Basel III as its integral part additionally emphasizes this importance for both banks and companies. Besides, in the countries with developed financial markets it is probably needless to mention the need for high quality debt securities. This is especially true due to the conditions of stronger institutional investors on the market, such as pension funds that can realistically be expected to become the leading financial institutions of the $21^{\text {st }}$ century, and ever increasing need of institutional investors, funds in particular, for high quality forms of assets and portfolio diversification. In EMCs in which pension reforms have still not been completely implemented or completed, considering a drastic fall in the ratio of the insured based on contribution payment and the number of pensioners, the existing situation is almost non-sustainable. Therefore, the transformation of pension funds in accordance to the two or three pillar structure and the emergence of voluntary pension funds as financially powerful institutional investors have no alternative.

Certainly, in terms of corporate bonds and their issue on the one hand, and investing in them on the other, in EMCs and thus also in $\mathrm{BiH}$ there are some important aspects to be observed when analyzing their influence on the decisions on financing or investing (liquidity, interest rate level, clarity and implementation of regulations, etc.).
\end{abstract}

Keywords: corporate bond markets, bank loans, emerging market countries, Bosnia and Herzegovina

\section{Introduction}

When a company decides to invest on a long-term basis, it can rely on usual sources of financing such as bank loans and/or proprietary capital or, as an alternative, it can raise the necessary funds by issuing bonds. If investors choose bond issuing, in turn, company will perform a series of fixed payments to investors, and after bond maturity nominal value will be paid as well. It is usual that corporate bonds give investors higher return rate than savings in banks or state issued bonds of similar maturity, simply due to the fact that corporate bonds are more risky (in accordance to the universally accepted investment rule "higher risk, higher return"). Besides, corporate bonds are considered safer investment than shares, bearing in mind the position of their holders in the hierarchy of distribution of company's business results but also its solvency mass, meaning that bondholders or creditors in general have a higher priority of debt settlement than owners.

If corporate bond market is functional (it enables concentration and supply-demand confrontation, establishes or "discovers" market prices and disseminates information) and strategically positioned as a part of the financial market and thus financial system, it can de facto play a significant role in stimulating EMC's economic growth. Namely, development of large infrastructural projects vitally important for EMC's economic growth is hard to imagine without capital. Consequently, companies need to provide stable sources of financing. However, choosing among various forms of financing is often limited by company's size and its financial position as well as by the level of capital market development and availability of other sources, including corporate bonds. 


\section{Theoretical Framework}

Corporate bond market importance particularly increases in the period of reducing ("suppressing") banks' credit activities as was the case in the period after the global financial crisis escalated in 2007-2008. First of all, concentration of credit risks and their inappropriate modeling in the banking sector led to a permanent increase in non-performing loan rate in the total credit amount, which is why banks reduced crediting small and medium enterprises (SMEs). This is when corporate bonds usually take the role of replacement mechanism for financing companies but also for stimulating investment, and economic development in general. Corporate bonds function not only as a substitution to bank loans but as their inevitable complement as well, especially in the new architecture of financial stability. Financing by bonds reduced company's dependence on banks, whose capacity to lend in certain situations can be decreased.

In the years of the global recession (2008-2012), the last reform of regulations related to bank business activities, aimed at preventing a new global financial crisis, started by the adoption of the so called Basel III by financial regulators of 27 world states on September 12, 2010. The reform set forth the new rules that per se included more severe demands for capital and bank solvency. For example, even though the ratio of the total capital and risk-weighted assets remained the same (8\%), the ratio of the primary capital increased from 2 to as many as 7\%, including the so called capital buffer. The fear that this would have the consequences in reduced placing of bank loans proved to be legitimate. In Europe, the Middle East, and Africa, bank loans decreased from \$1.4 trillion in 2007 to $\$ 400$ billion in 2012, even though Basel III gradual implementation was planned for the period from the beginning of 2013 to the beginning of 2019 (see Figure 1). (Note 1).

Reduction of banks' credit activities can have a disproportionally large influence on the real economy, especially in cases where banks are most prominent in financing companies' debts, as is the case with EMCs that, by the definition, have bank-centric financial systems of financial systems oriented towards banks not stock markets. Without an alternative such as corporate bonds, economic flows can be completely slowed down. Therefore, it can be said that corporate bonds are a backup mechanism (figuratively speaking "spare tire"), enabling constant financing of companies and reduction of financial risks in economy. In this respect, one of the most influential chairmen of the US Federal Reserve System ever, Alan Greenspan, metaphorically expressed the importance of corporate bonds as "spare tire" that is always ready to be actively used, especially in the times when other mechanisms of financing went flat (Torre de la \& Schmukler, 2007).

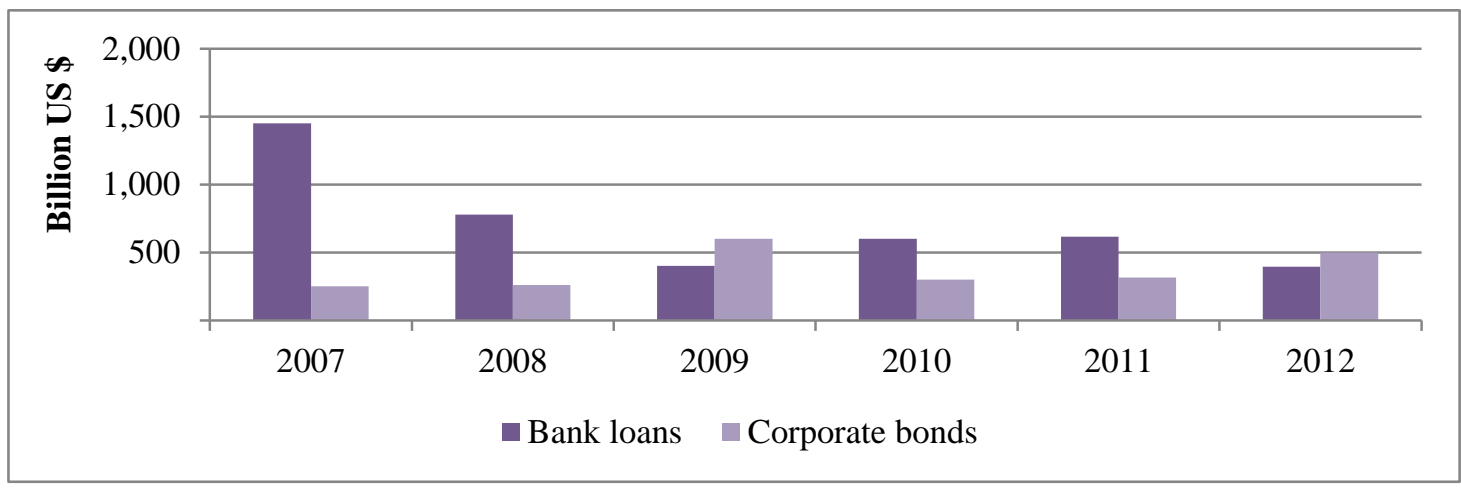

Figure 1. Scope of long-term financing in Europe, the Middle East, and Africa in the period 2007-2013

Source: ICMA (2013), p. 19.

Since in EMCs companies are largely dependent on bank credits, they face additional challenges when the banking sector is not prepared to ensure the lent capital efficiently. For example, the banking sector in $\mathrm{BiH}$ enormously favors banks, meaning the foreign banks that hold as much as $95 \%$ of the total assets and $90 \%$ of the stock capital and impose enormous and unnecessary costs to individual and legal persons. This is proved by the unofficial fact that net interest margin of $\mathrm{BiH}$ banks is $5.9 \%$ on average; while in Croatia it is significantly lower, $2.3 \%$.

Corporate bond markets in EMCs are expected to fulfill the following goals (WB \& IMF, 2001, p. 361):

- Reduce pressure on the banking sector and risk diversification in economy,

- Provide stable source of financing for companies, 
- Reduce financing costs,

- Provide flexible financial product so as to meet specific demands by investors and debtors, and

- Make information public and increase corporate management transparency.

Since corporate bonds are most often used as a form of savings, that is postponing spending in the form of savings and acquiring increased value in a future time period, investors mainly buy them to keep them until their maturity date. This directly causes fairly lower fluctuation on the secondary markets of corporate bonds, particularly in comparison to stock markets. In this way corporate bond markets help companies, providing them with stable and reliable sources of financing for business activities and development. Furthermore, financial stability has a practically proved influence on economic growth and development of a country. Also, there is a constant need for reducing company financing costs. That is why a high level of competitiveness among various market participants and financing options contributes to more efficient allocation of financial resources and maximization of economic benefits. In other words, corporate bonds "in a race" with other sources of financing such as stock capital or bank loans, exert constant pressure on the reduction of company financing costs.

Most often, corporate bonds have fixed financing terms, which are primarily defined by company's market position. This enables that payments on the basis of bonds issued and bond maturity match in time with the expected cash flows of the company. Generally speaking, corporate bonds are considered to be more efficient than bank loans in overcoming the problems caused by lack of harmonization between maturity dates and cash flows as well as in minimizing "maturity transformation" of assets. By providing a precisely defined amount of capital for a defined time period, corporate bond markets provide companies with flexible and target financing.

Moreover, encouraging new items and competitiveness between banks and non-banking financial institutions contributes to diversification of financial risk in economy and reduction of costs of external financing. Corporate bond markets also increase liquidity of the entire financial system, thus additionally stimulating country's economic growth.

\section{A Review of Previous Research}

Despite a significant role given to corporate bond markets, even in developed countries much less attention in academic papers is given to the implications of corporate bond market development in relation to stock markets. The gap is particularly evident in terms of empirical research and, to our knowledge, the main reason is the availability of the relevant data or limited access to the necessary data.

In order for financial markets, including corporate bond markets, to be efficient, transparent and stable, a set of prior conditions need to be fulfilled in the function of restructure and economic development. It is advisable to mention the research made by Feldman and Kumar (1994, p. 34), whose results showed that bond market can speed up the process of transition into market economy and contribute to economic growth, provided that the following assumptions are fulfilled:

- It is necessary to provide macroeconomic and fiscal environment that would offer high quality securities with the appropriate demand.

- It is necessary to create legal, regulatory, and institutional infrastructure that would ensure efficient and transparent trade on security markets.

The European Central Bank (ECB, 2001) proposed the initiative for a survey of the development of stock markets, corporate bond markets, banking mediation, and risk capital market in the period 1997 to 2000. The results of the survey are summed up in the section named "Theoretical analysis of corporate finance issues and external sources of corporate finance", which emphasizes strong expansion on the markets of debt securities as well as on risk capital markets. However, the survey also suggests a lower importance of corporate bond markets in the Eurozone than in the USA and Japan.

Haiss and Marin (2005) analyzed the development of corporate bond markets in the countries of Central and Eastern Europe (CEE). The authors concluded that corporate bond market is dominated by public issuers and the banking sector mediation. As in the European Union (EU), telecommunication companies and the service industry are those that mainly issue corporate bonds. It is an encouraging fact that the increasing demand of pension funds and limited volume of bank loans create the potential for growth of corporate bond markets in these countries.

An almost complete review of development of corporate bond markets is given by the Bank for International Settlements (BIS, 2006) for a group of Asian countries. Some of the reasons for exceptionally dynamic development of corporate bond markets in the countries of this region are: appropriate infrastructure, regulations, 
reliable investor bases, and mutual actions with banks. However, Asian markets are characterized by a low rate of trade, which is why the causes were examined of illiquidity of secondary corporate bond markets. Four key reasons of illiquidity are given as follows: (a) undiversified investor basis, (b) inappropriate market microstructure, (c) trade transparency, and (d) limited flow of timely information on issuers.

In terms of empirical studies, especially prominent are those that examine the relation between bond market development, economic growth, and the real sector. Some authors claim that corporate bond markets play an important role in improving financial infrastructure thus encouraging real economic growth. For example, Bondt (2002) and Fink, Haiss, and Hristoforova (2003) empirically examined the relation between the size of corporate bond market and economic growth. There is a general conclusion that increased rate of corporate bond issue can lead to economic impulses that in the end may result in economic growth. Besides, Fink, Haiss, and Hristoforova established weaker link between bonds in circulation and GDP growth for developed EU countries, while stronger link was identified for acceding and candidate countries (Note 2).

Recently, Kay and Meyer (2013) examined the activities on the primary corporate bond markets in the EU. They concluded that companies in the EU gradually decrease their dependence on bank loans and are successful in finding alternatives in the corporate bond market. Kay and Meyer emphasize several factors contributing to the expansion of corporate bond issue:

- Many European banks were forced to decrease debts in their financial reports due to high capital requirements and other regulatory changes and lack of capital.

- The gap between the bonds of the financial and non-financial sector is smaller, and in some market segments it even moved in favor of non-financial sector issuers.

- Demand for corporate bonds increased as a result of lower return on state bonds and changes in investors' preferences.

- Companies' management and owners became more open to financing via capital market.

Finally, what speaks in favor of development perspective of bonds in general and corporate bonds in particular, all over the world and in EMCs is the fact that when in 2011 "Bloomberg Markets" magazine asked ten leading billionaires to rate the best investments bearing in mind the recession trends, they gave similar answers: bonds, blue-chip stocks, Norwegian crown (NOK), and silver.

\section{The Recent Trends in Corporate Bond Market Development in EMCs}

In the last several years, the global bond market is on a significant increase, especially in the segment of non-financial corporate sector. In EMCs this increase is unprecedented in history.

In the countries of the Far East for example, issue of corporate bonds suddenly grew after the 1990 crisis. From almost a non-existent market in 1998 , in five years only, this market grew up close to $\$ 37$ billion. In the same period, an increase was registered in activities related to the issue of corporate bonds in highly developed countries as well. Nowadays, the total issue of bonds as a percentage of nominal GDP in developed economies is on average $25 \%$ while in EMCs it is $7 \%$ (Note 3).

There is a widespread opinion that the lack of developed corporate bond markets significantly contributed to the financial crisis that hit the Far East countries in the period 1997-1998. Namely, due to the lack of such markets, most capital influxes into these countries prior to the crisis, was in the form of short-term foreign loans that were made available to the economy via the banking sector. A rapid turnaround of such influxes and the related depreciation of foreign exchange rates exerted extreme pressure on the economic and banking sectors, which then led to a downfall of economic activities.

Consequently, in order to reduce the dependence on short-term bank credits and provide long-term financial stability, governments and other regulators tried to encourage development of corporate bond markets. The key aspect of Asian regulators' efforts was to improve market infrastructure, reduce issue costs, and initiate involvement of a higher number of domestic investors on such markets. At the ASEAN+3 group Finance Ministers' meeting held in August 2003, the Asian Bond Markets Initiative (ABMI) was endorsed to develop bond markets in the region (Note 4). The ABMI goal was to develop efficient and liquid bond markets so as savings would be used for investments in the region.

These efforts resulted in relatively rapid development of Far East corporate bond markets, in terms of absolute value and in relation to GDP. Regarding supply, the issue of corporate bonds received a powerful stimulus by regulatory initiatives aimed at harmonizing regulations and improving the relations among the region markets. On the other hand, an important moving force for the changes in terms of Asian companies' financing was the 
new regulatory challenges (the local and global ones) for banks. The challenges started with the publication of Basel II in 2004 and then Basel III six years later, and were related to the fact that higher capital requirements for banks may limit credit volumes to companies and generate higher demand for alternative forms of financing in the form of bond issue.

Corporate bond market in the Far East (not including Japan) grew to almost $\$ 3,000$ billion in 2013, while at the very beginning of the $21^{\text {st }}$ century its value was only $\$ 300$ billion. Figure 2 illustrates this sudden increase in financing by corporate bonds.

The data indicate that from the global financial crisis onwards Asian companies rely increasingly on financing by bond issue, thus extending the traditional channels of financing such as bank loans. It should be mentioned that the corporate bond market in this region provided a platform for financing not only companies from the private sector. State-owned companies are also important players on south-east Asian corporate bond markets, especially in China and Malesia.
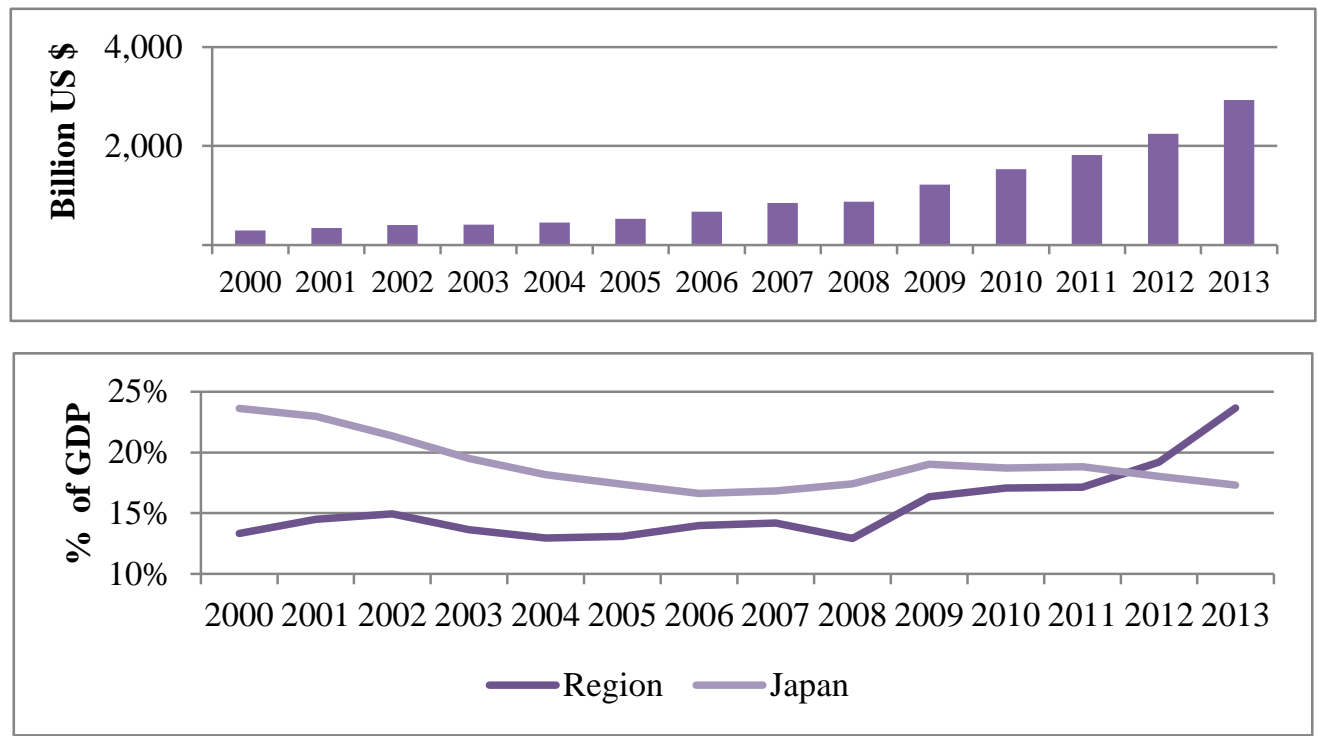

Figure 2. Corporate bonds traded in the Far East in the period 2000-2013

Note. The countries included in the Region are the Philippines, Indonesia, South Korea, China, Malaysia, Singapore, Thailand, and Vietnam. Source: Asian Bonds Online (2014).

However, certain aspects of Asian corporate bond markets are still relatively underdeveloped. To be specific, most corporate bonds are "in the hands" of a small number of domestic institutional investors that have a very similar investment strategy. Thus, despite the increased value of issue, secondary markets are still characterized by low trade volume, which limits further development of corporate bond markets in many Asian countries.

Apart from the Far East region, when observing development of EMCs corporate bond markets, attention should be paid to the CEE countries that underwent transformation and restructure of planned economy into market economy at the end of the last century. There was no institutional and legal structure for issuing and trading corporate securities in these countries. Financial sectors were designed primarily for monitoring and completing planned industrial manufacture and keeping macroeconomic stability. It was the central plan, not market forces, which determined distribution of financial resources. That is why there was no real need for security markets and corporate bond markets in particular. The transition process that was underway in CEE countries therefore demanded the establishment of a more efficient financial system and important reforms for financial markets.

Specific factors related to a particular country, such as historical, political, and other circumstances, required an individual approach to every CEE country. Financing by means of corporate bond issue in the developed western countries is characteristic of large companies. SMEs see this type of financing as too expensive. However, in CEE countries, SMEs are most active and they are the pillar of the economic system. On the other hand, large companies, which usually underwent privatization and were transformed from state-owned to private-owned structure, did not have a simple way of access to capital markets due to lack of investors' trust. The lack of trust 
on the demand side is primarily evident due to lack or cancelling of state guarantees. Investment into corporate bonds in CEE countries was also associated to a high level of uncertain settlement of high credit risk. One of the reasons lies in a rather low number of companies in the non-financial sector that have a satisfactory credit rating given by internationally recognized rating agencies. Besides, high inflation level characteristic of CEE countries in the 1990 was a significant obstacle to corporate bond issue. These and other reasons explain why corporate bond markets in this region developed at a slow pace.

After several years of economic transformation and reforms, CEE corporate bond markets started showing some signs of progress. Certain CEE countries became EU member states and adopted euro, which significantly influenced further development of corporate bond markets in the CEE region. Harmonization of regulations with those in the EU and market expansion opened up new possibilities for financing companies from these countries, primarily evident in an increased basis of investors and decreased requirements in the process of organization of bond issue.

Three leading countries in the level of development of capital market in CEE nowadays are Poland, Hungary, and the Czech Republic. These countries have the most developed stock and bond markets in terms of their size, liquidity, and instruments. Bond markets in Bulgaria and Slovakia experience a significant growth while other countries of the region, including Croatia and Slovenia, registered some progress in developing state and corporate bond markets (see Figure 3). Some less developed markets include $\mathrm{BiH}$, Serbia, Macedonia, and Montenegro, which are at the initial stages of development of state bond markets, while corporate bond markets are almost non-existent.

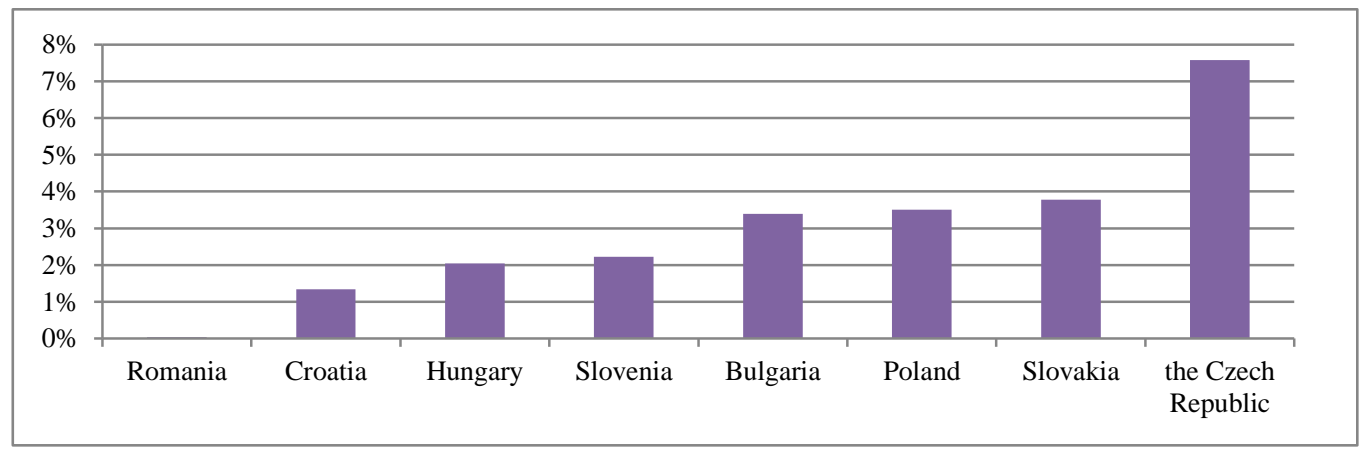

Figure 3. Corporate bonds of the non-financial sector in trade as a percentage of GDP of CEE countries in 2013

Source: ECB, Eurostat (2014).

More recently, with occasional falls, the issue of corporate bonds of the non-financial sector in CEE registered some positive trends. In 2012, a gradual "recovery" of the primary markets occurs, whereby the Czech Republic experienced a record-high value of volume of the issue (see Figure 4).

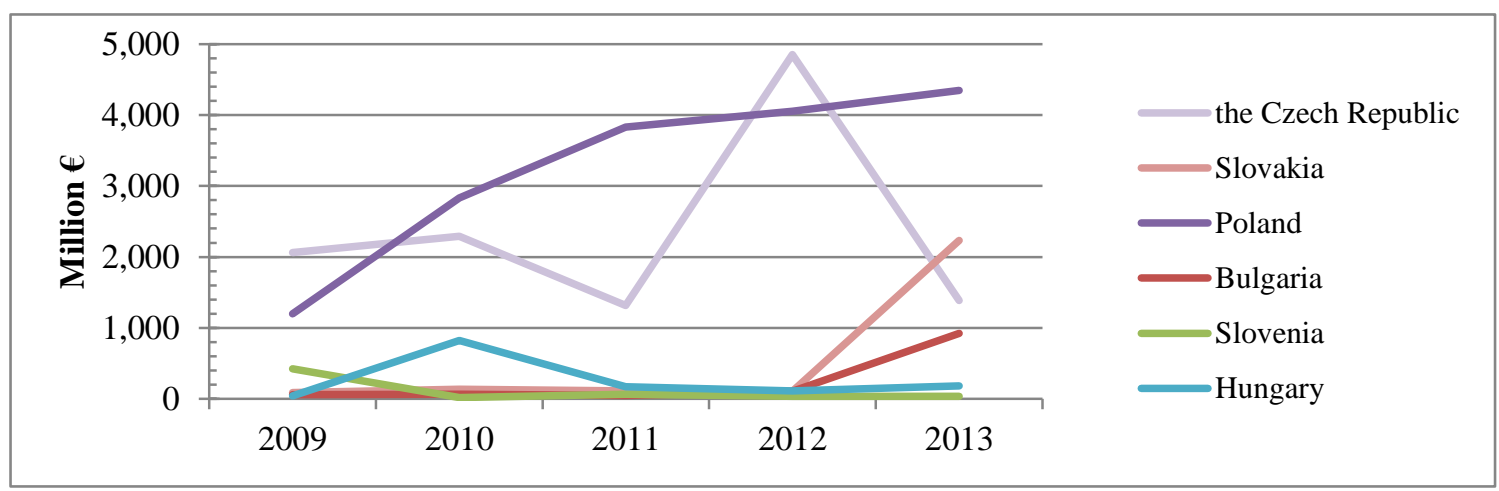

Figure 4. Value of the issue of corporate bonds of the non-financial sector in CEE countries in the period 2009-2013

Source: ECB, Eurostat (2014). 
As one of the CEE countries, $\mathrm{BiH}$ and its neighbors have a financial system dominated by banks, meaning the bank-centric financial system. The corporate bond market is still at its initial stage and not reliable or "strong-enough" alternative to bank credits. One of the reasons for insufficient development of this market is illiquid and underdeveloped capital market which simply turned into speculators' market due to stock market material lacking diversity, passive attitude of capital market institution, and lack of investment attitude.

These are all reasons why the primary corporate bond market in $\mathrm{BiH}$ is characterized by a rather small number of issues and their relatively low value. In the last five years, the only significant issue of corporate bonds (100 million BAM) was realized by Unicreditbank dd. Mostar. However, the entire issue was bought off by a mother bank, which is why the issue was not entrepreneurial in nature. Tables 1 and 2 present the review of past issues of corporate bonds in $\mathrm{BiH}$ entities: $\mathrm{BiH}$ Federation (F BiH) and Republic of Srpska (RS), respectively.

Table 1. Review of corporate bond issues in $\mathrm{F} \mathrm{BiH}$

\begin{tabular}{lccccc}
\hline Issuer & Issue date & Maturity date (year) & Nominal value in BAM & Number of securities issued & Coupon rate \\
\hline NLB Tuzlanska banka & 1 Feb 2008 & 3 & 100 & 50,000 & $5.75 \%$ \\
Unicredit Bank dd. & 1 Sep 2008 & 5 & 1,000 & 100,000 & $\begin{array}{c}(6-\text {-month } \\
\text { EURIBOR+-1\%)/2 }\end{array}$ \\
ASA Finance dd. & 3 Dec 2009 & 3 & 100 & 30,000 & $6.00 \%$ \\
Elektro Grupa dd. Jajce & 3 Sep 2012 & 2 & 10 & 100,000 & $7.00 \%$ \\
Massimo Holding doo. & 2 June 2014 & 6 & 100 & 5,000 & $8.00 \%$ \\
\hline
\end{tabular}

Source: Authors' research.

Table 2. Review of corporate bond issues in RS

\begin{tabular}{|c|c|c|c|c|c|}
\hline Issuer & Issue date & $\begin{array}{c}\text { Maturity date } \\
\text { (year) }\end{array}$ & $\begin{array}{c}\text { Nominal value in } \\
\text { BAM }\end{array}$ & $\begin{array}{c}\text { Number of } \\
\text { securities issued }\end{array}$ & Coupon rate \\
\hline Balkan Investment Bank ad. Banja Luka & 6 June 2007 & 3 & 100 & 5,000 & $6.05 \% *$ \\
\hline NLB Razvojna banka Banja Luka & 19 Sep,2007 & 2.5 & 100 & 50,000 & $5.75 \% *$ \\
\hline CER AD Prnjavor & 17 Oct 2008 & 5 & 1,000 & 450 & $10.00 \%$ \\
\hline Mikrokreditno društvo Sinergija PLUS & 23 Nov 2009 & 3 & 100 & 21,070 & $8.00 \%$ \\
\hline Farmland Nova Topola Gradiška & 26 Aug 2010 & 1 & 100 & 25,000 & $8.00 \% *$ \\
\hline Banka Srpske ad. Banja Luka & 30 Dec 2010 & 7 & 100 & 50,000 & $8.00 \%$ \\
\hline Planinsko dobro Nevesinje ad. & $4 \mathrm{Feb}, 2011$ & 2 & 100 & 10,000 & $6.75 \%$ \\
\hline Jahorina OC ad. Pale & 29 Mar 2011 & 15 & 1 & $15,000,000$ & $6.00 \%$ \\
\hline Atlantik BB doo. Banja Luka & 20 June 2011 & 4 & 100 & 15,000 & $7.20 \%$ \\
\hline Kaldera Company doo. Laktaši & 11 Jul 2011 & 20 & 100 & 70,000 & $6.00 \%$ \\
\hline Unis fabrika cijevi ad. Derventa & 15 Jul 2011 & 8 & 1 & $20,000,000$ & $7.50 \%$ \\
\hline Nova banka ad. Banja Luka & 24 Aug 2011 & 7 & 100 & 100,000 & $8.00 \%$ \\
\hline Boska RK ad. Banja Luka & 22 Sep 2011 & 12 & 100 & 150,000 & $7.00 \%$ \\
\hline Farmland Nova Topola Gradiška & 13 Aug 2012 & 3 & 100 & 35,000 & $8.00 \%$ \\
\hline Nova banka ad. Banja Luka & 30 Jan 2013 & 7 & 100 & 80,000 & $8.00 \%$ \\
\hline Nova banka ad. Banja Luka & 14 Jun 2013 & 7 & 100 & 100,000 & $8.00 \%$ \\
\hline Nova banka ad. Banja Luka & 13 May 2014 & 7 & 100 & 60,000 & $8.00 \%$ \\
\hline
\end{tabular}

Note. * Bonds were sold at a discount.

Source: Authors' research.

In the lack of true competition in the form of corporate bonds, the situation is currently such that banks dictate the conditions on the borrowed capital market. Direct consequences of such situation are above-average high costs of external financing for companies in $\mathrm{BiH}$. 


\section{Methodology of the Empirical Research and Discussion of the Results (The Case of Bosnia and Herzegovina)}

Corporate bond market is specified by institutional and legislative framework but also by supply and demand for securities. Since legislative and institutional framework (market infrastructure) has existed in $\mathrm{BiH}$ and has been operative for a number of years, one of the goals of this empirical research was to examine potential supply and demand on the corporate bond market in $\mathrm{BiH}$.

The research was conducted by means of a survey method and questionnaire. The questionnaire included two different samples. The first sample comprised companies from the group of 100 most successful companies in $\mathrm{BiH}$, measured by the total profit in 2012. The list of companies was taken from the project of "Poslovne novine" (i.e. Business News magazine) named "100 biggest companies in BiH", 2013 issue (Note 5). All companies listed are organized as limited liability companies or shareholding companies. Therefore, pursuant to the valid legal regulations in both $\mathrm{BiH}$ entities, BiH Federation and Republic of Srpska, they are potential issuers. Besides, all the companies observed fulfill the legal criteria related to large companies that are, in an EMC, expected to have the "capacity" to issue bonds (Note 6). The other sample included legally qualified institutional investors in $\mathrm{BiH}$. Regarding the valid legal regulations they include banks, insurance companies, and investment funds. It should be noted here that the financial literature recognizes the term "institutional investors" as investment funds, pension funds, and insurance companies. However, pursuant to the Law on Security Market in BiH Federation and the Law on Security Market of Republic of Srpska banks are also defined as institutional investors, which is why banks were included in the sample. The pension funds in $\mathrm{BiH}$ are organized at the entity levels and they are publicly owned. Long-waited pension reform, announced in 2008, has still not actually started. The number of insured persons based on contribution payment in relation to the number of pensioners is record low, 1.15:1, even though this system, organized by the pay-as-you-go principle, is known to be sustainable at the level of 3:1 minimum. When this system was initially introduced in Germany at the end of the $19^{\text {th }}$ century, this ratio was as much as 7-10:1. Voluntary pension funds, as potentially very active players on the financial market, are practically non-existent in $\mathrm{BiH}$.

The research was conducted by means of four questionnaires. Questionnaire number 1 examined the attitudes of companies on financing by various financing instruments, with the emphasis on bond issue financing. The remaining three questionnaires examined the attitudes of potential investors on investing a part of their portfolio into corporate bonds of domestic issuers. The questionnaire return rate was rather satisfactory: $30 \%$ for the company sample and $51.76 \%$ for the investor sample.

In terms of financing, companies in BiH dominantly rely on bank loans. In order to examine companies' interest in financing by bond issues, the level of their reliance on bank loans and the amount of resources required were examined first. The traditional reliance on bank loans is one of the causes of underdevelopment of the corporate bond market. However, whether the decision makers would consider alternative forms of financing or not depends on their thorough knowledge on the possibilities offered by other forms of financing.

The responses of the surveyed companies indicated that as many as $80 \%$ of them use long-term bank loans as the method of financing. The importance of banks in companies' financing in $\mathrm{BiH}$ is indicated by the fact that the largest number of subjects borrowed from five or more banks (Figure 5).

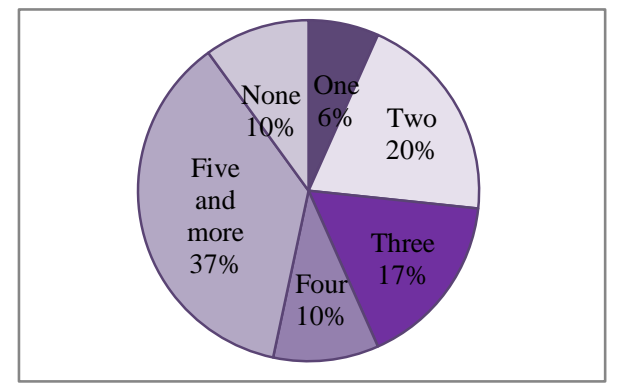

Figure 5. Number of banks crediting a company

Long-term financing by means of leasing was used by $37 \%$ of the subjects, while $10 \%$ used share issue. The lowest number of the companies surveyed, $3.33 \%$, used bond issue as a form of long-term borrowing (see Figure $6)$. 


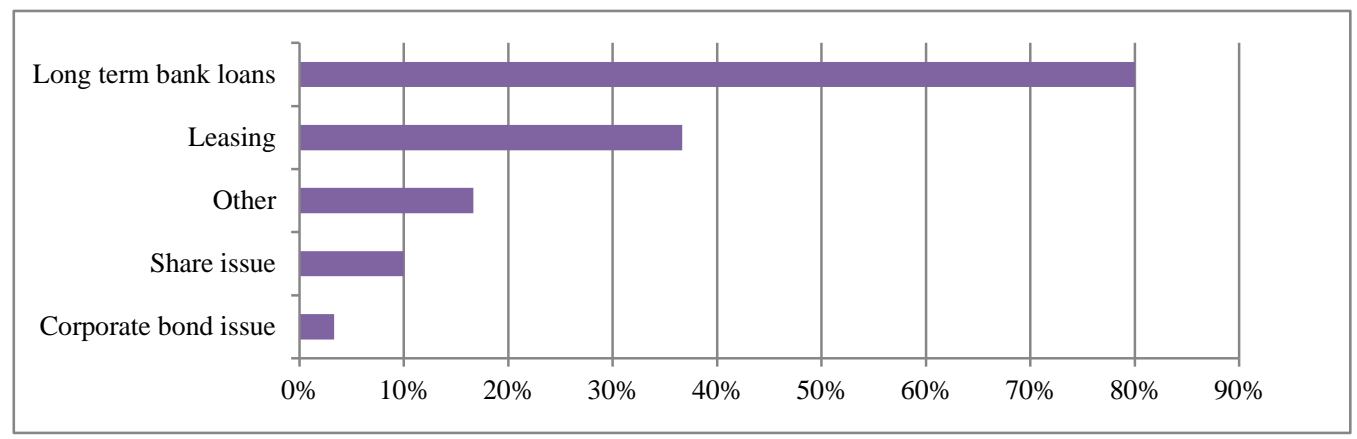

Figure 6. Long-term sources of financing for companies

The liabilities that issuers have based on selling bonds are basically the same as loan obligations towards banks. However, the fact that long-term bank loans are used in $80 \%$ and corporate bonds in only $3.33 \%$ of the cases indicates that the latter is completely undermined. This certainly means that, for activating this financing instrument, some opportunities need to be found and made more attractive than those for bank credits. Polić (2010, p. 275) states that the opportunities for more active presence of bonds can be seen in finding the difference between the interest rate approved by banks on time-deposit savings and the active interest rate paid by companies on long-term credits. Proper positioning of the coupon rate between these two points would provide mutual benefit to both issuers and investors.

Most companies use borrowed financial resources to invest in fixed assets and/or to expand their businesses, while one third of the companies use these resources to refinance previously started investment. In a questionnaire, companies were offered seven factors when selecting a bank loan, and they were supposed to rate them by their significance (Table 3 ).

The crucial factor in selecting a bank loan for the highest number of companies is flexibility offered by banks during negotiating the credit terms (vis-à-vis issued bonds, bank loans are more subject to sudden changes in financing terms). The advantage of loan also lies in information confidentiality, which is evident in $54 \%$ of the companies surveyed that appreciate the relevance of information secrecy. Companies in $\mathrm{BiH}$ are more open to reveal their business information to banks then to a wide set of users, which is demanded by the prospect of the issue of securities. A half of the companies rate highly the speed at which they acquire the necessary financial resources. When we consider the time necessary for obtaining financial resources by means of corporate bond issue, the advantage of banks is evident. Some practical experience show that even under "normal" circumstances, the issue realization can last up to six months, whereby the period is somewhat shorter in RS then $\mathrm{F} \mathrm{BiH}$. Investment counseling is almost irrelevant for making a decision on financing large companies in $\mathrm{BiH}$.

Table 3. Relevance of factors when making a decision on financing companies by bank credit

\begin{tabular}{lccccc}
\hline \multirow{2}{*}{ Factor } & "extremely low" & "low" & "medium" & "high" & "extremely high" \\
\cline { 2 - 6 } & 1 & 2 & 3 & 4 & 5 \\
\hline Speed in realization of loan application & $0.00 \%$ & $0.00 \%$ & $21.43 \%$ & $28.57 \%$ & $50.00 \%$ \\
Keeping company's business information safe & $3.57 \%$ & $10.71 \%$ & $10.71 \%$ & $21.43 \%$ & $53.57 \%$ \\
Flexibility in negotiating loan terms & $0.00 \%$ & $3.57 \%$ & $0.00 \%$ & $39.29 \%$ & $57.14 \%$ \\
Investment counseling & $17.86 \%$ & $21.43 \%$ & $28.57 \%$ & $25.00 \%$ & $7.14 \%$ \\
Possible changes in negotiated loan terms & $3.57 \%$ & $10.71 \%$ & $25.00 \%$ & $17.86 \%$ & $42.86 \%$ \\
Lack of alternative forms of financing & $26.92 \%$ & $15.38 \%$ & $19.23 \%$ & $19.23 \%$ & $19.23 \%$ \\
\hline
\end{tabular}

The third part of the questionnaire given to the companies covers the question aimed at establishing the probability for bond issue and the reason why companies opt or not for bond issue. All companies have growth potential and are in need of large financial resources. This is proved by the fact that $87 \%$ of the companies surveyed need more than 4 million BAM (approx. 2,045,200 euros) to finance their growth in future.

The companies were offered to rank all the financing sources when implementing the growth strategy (Table 4). Among the companies surveyed, as expected, the largest number gave the highest priority to financing via bank 
loan. A third of the companies identified significant presence of financing growth by corporate bond issue.

Table 4. Ranking sources of financing by the implementation of growth strategy

\begin{tabular}{lccccc}
\hline \multirow{2}{*}{ Source of financing } & "extremely low" & "low" & "medium" & "high" & "extremely high" \\
\cline { 2 - 5 } & 1 & 2 & 3 & 4 & 5 \\
\hline Share issue & $45.83 \%$ & $25.00 \%$ & $12.50 \%$ & $12.50 \%$ & $4.17 \%$ \\
Corporate bond issue & $33.33 \%$ & $33.33 \%$ & $12.50 \%$ & $12.50 \%$ & $8.33 \%$ \\
Financing by means of bank loan & $0.00 \%$ & $14.29 \%$ & $14.29 \%$ & $39.29 \%$ & $32.14 \%$ \\
Leasing & $20.00 \%$ & $24.00 \%$ & $32.00 \%$ & $12.00 \%$ & $12.00 \%$ \\
\hline
\end{tabular}

The companies that considered bond issue see lower capital costs and reduced exposure to commercial banks as the most important reasons (Table 5). Some other factors of company's financing by means of bonds include keeping control over the company and the financial result as well. A positive effect of a potential issue on company's reputation was marked as a less important factor.

Table 5. Relevance of factors at making potential decisions on bond issue

\begin{tabular}{|c|c|c|c|c|c|}
\hline \multirow[t]{2}{*}{ Factor } & "extremely low" & "low" & "medium" & "high" & "extremely high" \\
\hline & 1 & 2 & 3 & 4 & 5 \\
\hline $\begin{array}{l}\text { Better harmonization of company's asset and liability terms } \\
\text { of payment }\end{array}$ & $0.00 \%$ & $0.00 \%$ & $25.00 \%$ & $50.00 \%$ & $25.00 \%$ \\
\hline $\begin{array}{l}\text { Marketing effects of market activity transparency and issuer } \\
\text { exposure }\end{array}$ & $0.00 \%$ & $50.00 \%$ & $0.00 \%$ & $25.00 \%$ & $25.00 \%$ \\
\hline Most often practical without collaterals & $0.00 \%$ & $25.00 \%$ & $0.00 \%$ & $50.00 \%$ & $25.00 \%$ \\
\hline Lower capital costs & $0.00 \%$ & $0.00 \%$ & $25.00 \%$ & $25.00 \%$ & $50.00 \%$ \\
\hline Reduced exposure to commercial banks & $0.00 \%$ & $0.00 \%$ & $25.00 \%$ & $25.00 \%$ & $50.00 \%$ \\
\hline Bondholders do not participate in extra profit distribution & $0.00 \%$ & $0.00 \%$ & $25.00 \%$ & $75.00 \%$ & $0.00 \%$ \\
\hline Keeping control over company & $0.00 \%$ & $0.00 \%$ & $25.00 \%$ & $75.00 \%$ & $0.00 \%$ \\
\hline
\end{tabular}

The most important factors affecting companies' reluctance to finance by means of bond issue are as follows: longer time period to business deal realization, unknown costs of issue, and risk of issue placing. Most companies surveyed believe that banks do not provide significantly better terms of financing. It can therefore be assumed that the important reasons for non-issuing bonds are lengthy procedure of issue and uncertainty in terms of its realization (see Table 6).

Table 6. Relevance of factors affecting lack of decision on financing by means of bonds

\begin{tabular}{lccccc}
\hline \multirow{2}{*}{ Factor } & "extremely low" & "low" & "medium" & "high" & "extremely high" \\
\cline { 2 - 6 } & 1 & 2 & 3 & 4 & 5 \\
\hline Banks provide better terms of financing & $13.04 \%$ & $13.04 \%$ & $39.13 \%$ & $26.09 \%$ & $8.70 \%$ \\
Unconditional obligation to pay interest (unlike dividends) & $12.50 \%$ & $20.83 \%$ & $41.67 \%$ & $16.67 \%$ & $8.33 \%$ \\
Longer period until realization & $0.00 \%$ & $12.50 \%$ & $25.00 \%$ & $41.67 \%$ & $20.83 \%$ \\
Uncertainty in terms of costs of corporate bond issue & $0.00 \%$ & $12.50 \%$ & $37.50 \%$ & $41.67 \%$ & $8.33 \%$ \\
Unknown legal framework & $0.00 \%$ & $12.50 \%$ & $37.50 \%$ & $20.83 \%$ & $29.17 \%$ \\
Unknown investment risks & $4.17 \%$ & $12.50 \%$ & $16.67 \%$ & $29.17 \%$ & $37.50 \%$ \\
Obligatory transparency of business activities towards the & $20.00 \%$ & $28.00 \%$ & $20.00 \%$ & $20.00 \%$ & $12.00 \%$ \\
public & & & & \\
Objective limits of bonds as source of financing & $0.00 \%$ & $14.29 \%$ & $33.33 \%$ & $38.10 \%$ & $14.29 \%$ \\
\hline
\end{tabular}


It is interesting to take a look at the answers to the question regarding the key obstacles in development of companies' financing by means of bond issue in $\mathrm{BiH}$. The research results show that the most important factors affecting companies' financing by means of bond issue are under development of corporate and state bond market and macroeconomic and political instability (Table 7).

Table 7. Obstacles to companies' financing by corporate bond issue in $\mathrm{BiH}$

\begin{tabular}{lccccc}
\hline \multirow{2}{*}{ Obstacle } & "extremely low" & "low" & "medium" & "high" & "extremely high" \\
\cline { 2 - 5 } & 1 & 2 & 3 & 4 & 5 \\
\hline Macroeconomic and political instability & $3.57 \%$ & $10.71 \%$ & $14.29 \%$ & $21.43 \%$ & $50.00 \%$ \\
Lack of entrepreneurial activity & $0.00 \%$ & $21.43 \%$ & $32.14 \%$ & $32.14 \%$ & $14.29 \%$ \\
Lack of knowledge on this form of financing & $3.57 \%$ & $21.43 \%$ & $17.86 \%$ & $21.43 \%$ & $35.71 \%$ \\
Underdeveloped market of state bonds & $3.57 \%$ & $3.57 \%$ & $10.71 \%$ & $28.57 \%$ & $53.57 \%$ \\
Underdeveloped market of corporate bonds & $0.00 \%$ & $3.57 \%$ & $3.57 \%$ & $28.57 \%$ & $64.29 \%$ \\
Legal regulations & $3.23 \%$ & $6.45 \%$ & $25.81 \%$ & $32.26 \%$ & $32.26 \%$ \\
\hline
\end{tabular}

When making the decision on company's financing by means of bond issue, the expected outcome of issue or its success is of extreme importance. In $\mathrm{BiH}$, the issue of corporate bonds by means of public offer is considered successful if at least $60 \%$ of the bonds issued are bought. Certainly, issuers would hope for the percentage to be as high as possible so that they would satisfy their needs for financial resources.

In case of unsuccessful issue, company may, beside the lack of financial resources, face the risk of changing its perception in the public. That is why company should, prior the bond issue, develop positive perception on its business activities, which would ensure a higher number of surplus units (subjects) wanting to extend their investment portfolios by its securities. Creating securities by investors' needs is the shortest road to successful issue. Prior to making a decision on the issue, company needs to know demand level and potential interest of investors in this type of securities.

Aimed at analyzing desirability of corporate bonds in the property structure of qualified investors on the financial market in $\mathrm{BiH}$, a survey was made in banks, investment funds, and insurance companies. The questionnaires were adapted to each group of subjects, bearing in mind that the majority of questions are adjusted, for the purpose of mutual comparability and collective interpretation. The questions were made to analyze the interest in investment into domestic corporate bonds and reveal the obstacles for activation the corporate bond market in $\mathrm{BiH}$.

The results showed that about one third of the institutional investors (32\%) have experience in bonds of domestic companies. However, there is evident difference among institutional investors when it comes to tradition of investing in corporate bonds. None of the banks surveyed has ever invested in corporate bonds so far, although some $20 \%$ of them have experience in investing in municipal bonds that have a smaller market. However, this does not come as a surprise since the primary activity of the banks in $\mathrm{BiH}$ is not investment into securities. Namely, BiH banks apply the so called conservative, core business approach. Some $16 \%$ of the insurance companies surveyed stated that they invested into corporate bonds. The highest percentage of investors in corporate bonds was found among investment funds, which is quite understandable. Some $52 \%$ of them gave a positive answer to this question.

When asked about their intentions to invest into domestic corporate bonds, 57\% of the investors surveyed gave a positive answer. Some $65 \%$ of the investment funds surveyed are ready to invest into corporate bonds in the future, along with more than a half of insurance companies (7 out of 12) and three banks. Out of those ready to invest, two thirds plan to invest $1-5 \%$ of their investment portfolios in corporate bonds, while somewhat less than a third are prepared to invest up to $10 \%$ of their portfolio. Certainly, readiness and possibilities for investment need to be analyzed from the aspect of legal regulations. Besides, a strong relation was identified in investment funds between the readiness for investment in the future and their past experiences in corporate bond investment.

Finally, Table 8 shows the answers given by institutional investors to the question about obstacles to development of the corporate bond market. Over $70 \%$ of the subjects believe that the insufficient number of issuers along with political and economic division in $\mathrm{BiH}$ is an extremely serious obstacle. Also, a half of the 
subjects identified the following elements as large obstacles as well: insufficient number of securities, legal regulations, and insufficient education (low financial literacy) on behalf of investors.

Table 8. Relevance of obstacles to development of the corporate bond market in $\mathrm{BiH}$

\begin{tabular}{lccccc}
\hline \multirow{2}{*}{ Obstacle } & "extremely low" & "low" & "medium" & "high" & "extremely high" \\
\cline { 2 - 6 } & 1 & 2 & 3 & 4 & 5 \\
\hline Subject to speculation & $11.90 \%$ & $7.14 \%$ & $33.33 \%$ & $14.29 \%$ & $33.33 \%$ \\
Legal regulations & $2.50 \%$ & $10.00 \%$ & $37.50 \%$ & $20.00 \%$ & $30.00 \%$ \\
Insufficient number of issuers & $0.00 \%$ & $12.20 \%$ & $9.76 \%$ & $19.51 \%$ & $58.54 \%$ \\
Insufficient number of securities & $2.44 \%$ & $12.20 \%$ & $31.71 \%$ & $14.63 \%$ & $39.02 \%$ \\
Uneducated investors & $0.00 \%$ & $7.50 \%$ & $37.50 \%$ & $22.50 \%$ & $32.50 \%$ \\
Political and economic division of BiH & $7.14 \%$ & $9.52 \%$ & $11.90 \%$ & $19.05 \%$ & $52.38 \%$ \\
\hline
\end{tabular}

\section{Conclusion and Recommendation}

EMCs, including BiH, have the financial systems oriented towards banks, not stock markets. This is why bank loans dominate in the financing of companies. However, the change in the architecture of financial stability in 27 world countries, and indirectly in the rest of the world (as a consequence of banking activity internationalization), primarily through the adoption of Basel III, may further aggravate credit activities of banks and slow down economic activities on the global scale. This is why it is important for EMCs to keep developing their financial markets and market infrastructure in the full sense. This development per se involves the segment of corporate bonds.

From the aspect of financing alternatives and available financial instruments, the financial market in $\mathrm{BiH}$ is extremely underdeveloped. This market is dominated by the banking sector which is largely foreign-owned. The global financial crisis that indirectly hit the country at the end of 2008 left a deep mark in the lack of trust in capital market, which has not recovered after more than six years. These extremely worrying characteristics of the financial market in $\mathrm{BiH}$ oblige and impose the need for finding serious alternatives for companies' financing. Besides constant risks of foreign capital withdrawal from banks, slowdown of banks' credit activities is also evident, especially in the segment related to long-term credits to the economic sector. Banks' restrictive loan terms seriously destabilize the total economic activity in $\mathrm{BiH}$, which is why the activation of the corporate bond market may de facto help faster economic recovery.

The companies in $\mathrm{BiH}$ have so far been mainly oriented to the sources of financing not at all related to corporate bonds. However, the significant interest in financing by means of bond issue is rather encouraging. This interest of companies in $\mathrm{BiH}$ creates advantages that reflect in high quality influence on solvency, elimination of limits related to securing collaterals, lower exposure to banks, and consequently, lower costs of financing. On the contrary, companies identify the key barriers to one step forward towards bond issue as follows: unknown details related to the length of the process, issue costs and placing risks, with stressed lack of knowledge of the legal framework for implementing corporate bond issue, which is mainly the consequence of underdeveloped corporate management in $\mathrm{BiH}$ companies and, unfortunately, of still prevailing "ruling" (i.e. the owner of himself/herself makes key business decisions).

It is particularly encouraging that the potential on the side of demand for corporate bonds is definitely there. For example, the October 2014 data show that the total savings concentrated in BiH banking sector is at the record level of 9 billion BAM (approx. 4.6 billion euros). Despite a low level of development of the corporate bond market in $\mathrm{BiH}$, there is a significant number of institutional investors, especially investment funds, that have so far had some experiences in investing into corporate bonds. A more prominent share of corporate bonds in the portfolios of institutional investors in $\mathrm{BiH}$ includes a wide variety of issuers and better legal basis, which these investors see as the key barriers. Besides, expected pension reform in the country has no alternative and thus voluntary pension funds may become one of the key investors in corporate bonds.

The directions of possible actions on improving the capital market in $\mathrm{BiH}$ may be suggested. This can be done by recognizing the facts on the influence of corporate bond markets on the economic growth of EMCs and the possibilities offered by the market development in terms of limiting a predominant influence of banks in most financial systems of these countries, which sometimes impose unnecessary costs to individual and legal persons, 
in $\mathrm{BiH}$ in particular. Also, one needs to show the evident potentials on the side of both supply and demand for corporate bonds. All this requires appropriate legal forms to ensure short terms and efficient procedures of corporate bond issues which should not last longer than the approval of long-term loans at banks. It is important to mention that large-scale promotion of corporate bonds is necessary as well as intensive education of potential issuers and investors, both institutional and individual ones. The creators of the economic policy in BiH should pay special attention to the costs of corporate bond issue, which certainly must not be a barrier when potential issuers make their decisions on choosing this financial instrument, while for investors an equal treatment should be given to this type of investment in comparison to savings. Finally, in an objectively possible scope, the synergy of the market capital in BiH needs to be achieved (Sarajevo and Banjaluka stock markets), which would enable the creation of, if not unique, then at least equal legal and institutional environment for the issue and trade of corporate bonds.

\section{References}

Bank for International Settlements (BIS). (2006). Developing corporate bond markets in Asia. BIS Papers No. 26. Retrieved July 25, 2013 from http://www.bis.org/arp/conf_0602.pdf

Bondt, G. D. (2002). Euro area corporate debt securities market: First empirical evidence. Working Paper No. 164, European Central Bank, Frankfurt am Main. Retrieved July 30, 2013 from https://www.ecb.europa.eu/pub/pdf/scpwps/ecbwp164.pdf

European Central Bank, ECB. (2001). Characteristics of corporate finance in the euro area. ECB Monthly Bulletin, February 2001, p. 37-50.

Feldman, R. A., \& Kumar, M. S. (1994). Emerging equity markets: Growth, benefits and policy concerns. IMF paper on Policy Analysis and Assessment, PPAA/94/7.

Fink, G., Haiss, P., \& Hristoforova, S. (2003). Bond markets and economic growth. IEF Working Paper Nr. 49, University of Economics and Business Administration Vienna. Retrieved August 15, 2013 from http://core.kmi.open.ac.uk/download/pdf/11007252.pdf

Guscina, A., Pedras, G., \& Presciuttini, G. (2014). First-time international bond issuance: New opportunities and emerging risks. IMF Working Paper, WP/14/127, Monetary and Capital Markets Department. Retrieved November 25, 2014 from http://www.imf.org/external/pubs/ft/wp/2014/wp14127.pdf

Haiss, P., \& Marin, S. (2005). Options for developing bond markets: Lessons from Asia for central and Eastern Europe. EI Working Papers / Europainstitut, 63. Europainstitut, WU Vienna University of Economics and Business, Vienna. Retrieved December 10, 2013 from http://epub.wu.ac.at/1234/

International Capital Market Association, ICMA. (2013). Economic importance of the corporate bond markets (1st ed.). $\quad$ Retrieved $\quad$ April $\quad 15, \quad 2014$ from http://www.icmagroup.org/assets/documents/Media/Brochures/2013/Corporate-Bond-Markets-March-2013. pdf

Kaya, O., \& Meyer, T. (2013). Corporate bonds in Europe. Deutsche Bank DB Research, Frankfurt am Main. $\begin{array}{llll}\text { Retrieved May } \quad 10, & 2014 & \text { from }\end{array}$ https://www.dbresearch.com/PROD/DBR_INTERNET_EN-PROD/PROD0000000000312365/Presentation $\% 3 \mathrm{~A}+$ Corporate+Bonds+in+Europe\%3A+attractive+environment+for+bond+issuers.PDF

Law on Accounting and Auditing in Bosnia and Herzegovina Federation, Official Gazette of F BiH, No. 83/09.

Law on Accounting and Auditing of Republic of Srpska, Official Gazette of RS, No. 36/09 \& 52/11.

Law on Security Market in Bosnia and Herzegovina Federation, Official Gazette of F BiH, No. 85/08.

Law on Security Market of Republic of Srpska, Official Gazette of RS, No. 92/06 \& 34/09.

Polić, N. (2010). Primarno tržište: Može li tržište kapitala u BiH biti realna alternativa bankarskom sistemu. X međunarodni seminar "Korporativno upravljanje", zbornik radova, Dubrovnik, Revicon, pp. 269-282.

Torre de la, A., \& Schmukler, S. L. (2007). Emerging capital markets and globalization: The Latin American experience. A copublication of Stanford University Press \& the World Bank. http://dx.doi.org/10.1596/978-0-8213-6544.1

World Bank (WB) \& International Monetary Fund (IMF). (2001). Developing government bond markets. A

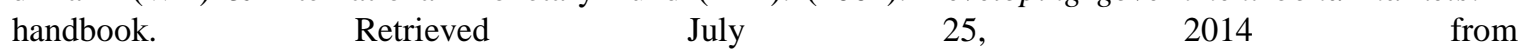
http://books.google.ba/books?id=s2BRPkh_x4sC\&printsec=frontcover\&hl=hr\&source=gbs_ge_summary_r $\& \mathrm{cad}=0 \# \mathrm{v}=$ onepage $\& \mathrm{q} \& \mathrm{f}=$ false 


\section{Notes}

Note 1. By the estimates of the Bank for International Settlements (BIS), world's largest banks would need to provide a total of 374 billion euros of additional capital so as to reach the required $7 \%$ rate of adequacy of the primary capital and become consistent with Basel III. Thus reactions to Basel III are both positive and negative. BIS heads stated that the new regulations on the required capital would make the world a safer place. The BBC business editor Robert Peston sees the new regulations as the most important global initiative for drawing a lesson from the global financial crisis in 2008 and its correction. However, some claim that the new regulations are mild to banks. One of the regulation authors, the former governor of the Central Bank of Holland, Nout Wellink, warned that the banking sector would have to raise hundreds of billions of euros so as to fulfill the requirements. He emphasized that banks will have to retain the profit for years, not being able to share it to shareholders of spend it on bonuses. Furthermore, some banks will have to provide additional assets on capital market.

Note 2. The survey included eight countries that were candidates for joining the EU or EU acceding countries at the time: Bulgaria, The Czech Republic, Slovakia, Hungary, Poland, Romania, Malta, and Turkey.

Note 3. For more details, see: (Guscina, Pedras, \& Presciuttini, 2014).

Note 4. ASEAN+3 includes ten members of the Association of Southeast Asian Nations (ASEAN) and three countries of the East Asia (China, Japan, and South Korea).

Note 5. "Poslovne novine" is an established monthly business magazine, issued by "Privredna štampa" doo. Sarajevo.

Note 6. Law on Accounting and Auditing in Bosnia and Herzegovina Federation (Official Gazette of F BiH, No. 83/09) and Law on Accounting and Auditing of Republic of Srpska (Official Gazette of RS, No. 36/09 and 52/11).

\section{Copyrights}

Copyright for this article is retained by the author(s), with first publication rights granted to the journal.

This is an open-access article distributed under the terms and conditions of the Creative Commons Attribution license (http://creativecommons.org/licenses/by/3.0/). 